\title{
FATE OF SEMINAL PLASMA AFTER INTRAUTERINE INSEMINATION IN THE PIG
}

\author{
R. H. F. HUNTER, * A. KARAGIANNIDIS $\dagger$ AND T. MANN \\ A.R.C. Unit of Reproductive Physiology and Biochemistry, \\ University of Cambridge
}

(Received 4th November 1971, accepted 8th December 1971)

The voluminous ejaculate of the domestic boar, often amounting to nearly half a litre, and the presence of 'gel' has attracted considerable comment since the studies of Lewis (1911), Rodolfo (1934) and McKenzie, Miller \& Bauguess (1938). Although it is known that seminal plasma constitutes most of the large volume, the physiological function and ultimate fate of the seminal plasma after deposition in the uterus remain undecided. There has been, however, general agreement on the rapidity of disappearance of seminal plasma from the uterine horns of oestrous pigs after mating (Lewis, 1911; du Mesnil du Buisson \& Dauzier, 1955; Mann, Polge \& Rowson, 1956) and this was attributed either to 'backflow' through the cervical canal (Rodolfo, 1934; McKenzie et al., 1938; Burger, 1952) or to absorption from the uterus (du Mesnil du Buisson \& Dauzier, 1955; Kvasnitsky, 1959; Pitkjanen, 1960; Rigby, 1964; Lovell \& Getty, 1968). The fluid portion of the boar seminal plasma is made up mainly of secretions from the urethral glands, epididymides and seminal vesicles, that of the seminal vesicles being characterized by the presence of citric acid, ergothioneine, fructose and inositol. Chemical determination of any of these four substances provides a convenient means for evaluating quantitatively the contribution of the vesicular secretion to the final composition of a boar ejaculate (Mann, 1964). Using this analytical approach, the present study was undertaken with the aim of clarifying the question of the presumed absorption of seminal plasma from the pig uterus.

Four (I to IV) cross-bred Large White $\times$ Essex gilts, weighing 120 to $140 \mathrm{~kg}$, were examined at laparotomy on the 1st or 2nd day of oestrus, under Nembutal-Fluothane anaesthesia. After confirming by examination of the ovaries that ovulation had not yet occurred, a double ligature of braided silk was placed at the caudal end of one uterine horn, approximately $10 \mathrm{~cm}$ from the uterine body, in such a way as to avoid ligating any major vessels. Gel-free semen $(100 \mathrm{ml})$ with a known content of spermatozoa $\left(1.2\right.$ to $\left.1.9 \times 10^{10}\right)$, citric acid (97 to $120 \mathrm{mg}$ ), ergothioneine (10 mg) and fructose (9 to $12 \mathrm{mg}$ ) was then injected directly into the lumen of the ligatured horn. The donors of the semen were two Large White boars (I and II).

From the ligated uterine horn of all four gilts in oestrus, samples $(3.5 \mathrm{ml})$ of the uterine contents were aspirated with a syringe at intervals of $3 \mathrm{~min}, 2 \mathrm{hr}$,

* Present address: School of Agriculture, University of Edinburgh, West Mains Road, Edinburgh 9.

$\dagger$ Present address: 4 Kavakion Street, Thessaloniki, Greece. 
$4 \mathrm{hr}$ and $6 \mathrm{hr}$, and, from Gilts I, II and IV, $24 \mathrm{hr}$ after intrauterine insemination. The body wall was closed with sutures between the collections. From each aspirated sample, $0.5 \mathrm{ml}$ was set aside for the determination of sperm concentration in a haemocytometer and the remainder was used for the preparation of protein-free extracts in which citric acid, ergothioneine and fructose were then determined by the methods described by Mann (1964).

The ligated uterine horns remained distended in all four gilts during the first $6 \mathrm{hr}$ after insemination. Even $24 \mathrm{hr}$ after insemination, the lumen still

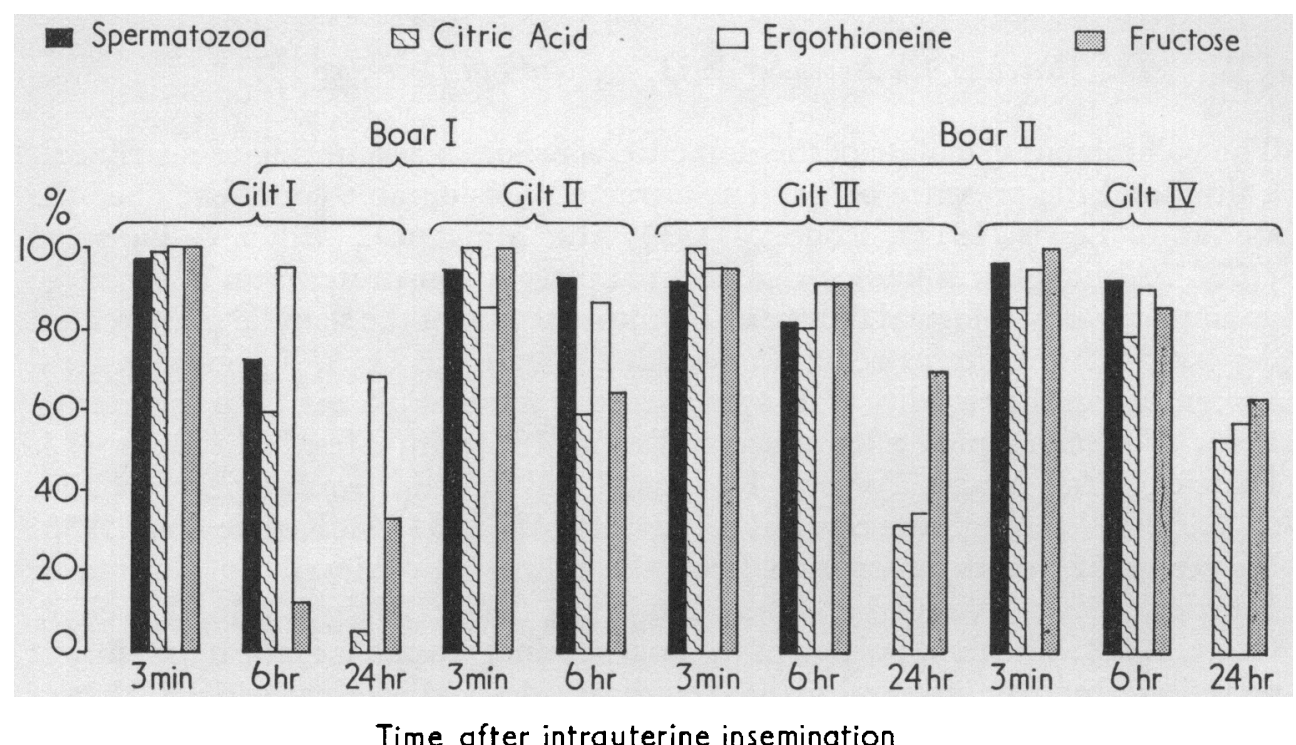

TEXT-FIG. 1. Decrease in the concentration of spermatozoa, citric acid, ergothioneine and fructose after intrauterine injection of boar semen. Results are expressed as a percentage of the initial concentrations in the ejaculate.

contained a considerable volume (range 18 to $105 \mathrm{ml}$ ) of a creamish-grey fluid. Up to $6 \mathrm{hr}$ after intrauterine insemination, the decreases in the concentration of spermatozoa, citric acid, ergothioneine and fructose in the uterine contents were small, certainly much smaller than the corresponding changes that occur after natural mating (Mann et al., 1956). Even $24 \mathrm{hr}$ after injection of the semen, the disappearance of citric acid, ergothioneine and fructose was by no means complete (Text-fig. 1), though the concentration of intact spermatozoa had by that time fallen to about $5 \%$ of the initial value, their presence being overshadowed by the large amount of other cellular material, mostly $(95 \%)$ polymorphonuclear leucocytes.

Taking into account the reservations which apply in general to all experiments involving anaesthesia and ligation of the uterus, our results appear, nevertheless, to indicate that absorption of seminal constituents from the uterus proceeds too slowly to account alone for the rapid disappearance of seminal plasma which occurs in the pig after natural mating. Some other mechanism, perhaps the backflow of semen through the cervix, must also contribute to the 
rapid post-copulatory loss of seminal plasma from the uterus of the oestrous pig after the establishment of a viable population of spermatozoa at the uterotubal junction (du Mesnil du Buisson \& Dauzier, 1955), in which case the secretion of gelatinous material by the boar during mating and the temporary occlusion of the cervical canal by that gel could be of some significance in delaying loss of semen from the uterus (McKenzie et al., 1938; Burger, 1952), particularly as regards substances such as fructose, citric acid and ergothioneine, which are present in the fluid portion of the boar ejaculate.

We wish to express our best thanks to Dr C. Polge for much valuable help. R.H.F.H. acknowledges the award of a Senior Research Fellowship by the Milk Marketing Board, and A.K. wishes to thank the Organization for Economic Co-operation and Development for his Research Fellowship.

\section{REFERENCES}

Burger, J. F. (1952) Sex physiology of pigs. Onderstepoort 7. vet. Res. Suppl. No. 2, 218.

du Mesnic du Buisson, F. \& Dauzier, L. (1955) Distribution et résorption du sperme dans le tractus génital de la truie: survie des spermatozoïdes. Annls Endocr. 16, 413.

Kvasnitsky, A. V. (1959) Méthode fractionnée d'insémination artificielle des truies. Annls Zootech. Series D, Suppl., p. 43.

Lewrs, L. L. (1911) The vitality of reproductive cells. Bull. Okla agric. Exp. Stn, 96, 3.

Lovelt, J. E. \& GetTy, R. (1968) Fate of semen in the uterus of the sow: histologic study of endometrium during the 27 hours after natural service. Am. 7. vet. Res. 29, 609.

McKenzie, F. F., Miller, J. C. \& Bauguess, L. C. (1938) The reproductive organs and semen of the boar. Res. Bull. Mo. agric. Exp. Stn, 279, 5.

Mann, T. (1964) The biochemistry of semen and of the male reproductive tract. Methuen, London.

Mann, T., Polge, C. \& Rowson, L. E. A. (1956) Participation of seminal plasma during the passage of spermatozoa in the female reproductive tract of the pig and horse. F. Endocr. 13, 133.

Pitrjanen, I. G. (1960) The fate of spermatozoa in the uterus of the sow. Zh. obshch. Biol. 21, 28 (Anim. Breed. Abstr. 28, 299).

RigBY, J. P. (1964) The fate of spermatozoa in the genital tract of the sow following artificial insemination. Proc. Vth int. Congr. Anim. Reprod., Trento, 4, 421.

Rodolfo, A. (1934) The physiology of reproduction in swine. II. Some observations on mating. Philipp. F. Sci. 55, 13. 